\title{
External Debts Management Strategies in Developing Economies: An Impact Assessment on Selected Economic Indices of Nigeria (2002-2011)
}

\author{
Uche Lucy Onyekwelu ${ }^{1}$, Emma Okoye ${ }^{1} \&$ Uche Boniface Ugwuanyi ${ }^{2}$ \\ ${ }^{1}$ Department of Accountancy, Nnamdi Azikiwe University, Awka, Nigeria \\ ${ }^{2}$ Department of Accountancy, Enugu State University of Science \& Technology, Enugu, Nigeria \\ Correspondence: Uche Boniface Ugwuanyi, Department of Accountancy, Enugu State University of Science \& \\ Technology, Enugu, Nigeria. E-mail: uchebrowntak@yahoo.com
}

Received: May 4, 2014

doi:10.5539/ijef.v6n8p137
Accepted: June 13, 2014

Online Published: July 25, 2014

URL: http://dx.doi.org/10.5539/ijef.v6n8p137

\begin{abstract}
This paper examines External Debts Management Strategies in developing economies and its implications on some key economic indices using Nigeria as a case study. This work has adopted both the content analysis and the empirical approach. Data for this study were basically secondary data. The quantitative data for analysis were gathered from the statistical bulletins/releases of relevant government agencies like the Debt Management Office, Central Bank and the Office of the Accountant General of the Federation. The qualitative information was sourced via textbooks, and scholarly journal publications accessed through the internet. Data were analysed using the Linear Regression and Analysis of Variance (ANOVA). The linear regression showed that there is a positive and significant relationship between the size of External Debts and Gross Domestic Product (GDP), Capital Expenditure, External Reserves and Exports. However, the Analysis of Variance (ANOVA) reveals a negative correlation between External Debts and the variables studied. The study attributes this anomaly to mismanagement of credit facilities, unfavourable loan terms characterized by capitalization/compounding of interests, weak economic base, poorly co-ordinated statistics on loans and overdependence on foreign aids among others. This development has led to poor performance of almost all the key economic indices of the country resulting in dearth of infrastructural development, very weak real sector, and high unemployment rate and so on. The paper recommends that developing economies should manage credits better by appropriating the funds to sectors that would ensure diversification of their economic base. Nigeria should pursue deliberate policy that will encourage a virile productive sector, place less emphasis on external borrowings as most of the credits are given under very unfavourable credit conditions and their repayments erode the much needed funds for economic development. The various governments should see external borrowings as a last resort and when contracted must be employed to finance only self- sustaining projects that will stimulate real sector and other factors of production needed to engender sustainable economic development.
\end{abstract}

Keywords: external debts, debt management strategies, developing economies

\section{Introduction}

\subsection{Background of the Study}

One of the key challenges facing developing countries is to achieve a level of economic development that can support sustainable growth and development (Omoruyi, 2004). However, resources are hardly adequate to finance all developmental programmes that are geared towards this objective. Often, the wide gap between available domestic resources or savings and the investments to be undertaken, Agho (2000) in Omoruyi (2004) notes leads to low productivity. The existence of this deficit often than not led developing countries to resort to external borrowings to bridge the savings/investment gap with an aim to fastracking economic growth and development. Duru and Anang (2006) note that many countries have borrowed extensively on commercial terms from creditor agencies and raised funds from international banks and capital markets to supplement the available resources.

Soludo (2008) and Anyanwu (1997) note that many debtor countries have obtained credits on concessional terms from governments and multilateral development institutions have set up units in their central banks and 
ministries of finance to manage such debts. These units they note have developed strategies to negotiate and administer such debts. The above scenario brings to the fore some of the attendant complexities external debt management the burden/responsibilities such countries will have to contend with. Other developing economies have deviced policies to guide them during loan negotiations as well as strategies towards loan repayments. This has become necessary as a loan will turn out to be good or bad depending on its negotiation terms and utilization.

Silua (2000); Eichengreen and Wypo (1996) advocated a need for industrial economies to monitor and regulate the flow of funds to developing countries to match their requirements for development as represented in the Dual-Gap-Model with development in their capacity to meet external debt obligations. Eichegreen argues that emphasis should be more on the role of economic reforms in spurring growth in developing economies with a view to enhancing their debt service capacities. The problem of External debt crisis has deepened as noted by Enyiuche and Obiefuna (2011) as highly indebted countries saw the accumulated debts as a tax on prospective future outputs as this discourages productivity and investments. Anyanwu (1993) submits that the reduced investment experienced by debtor countries could result from negative effect of tax disincentive as the funds generated are used for interest payment noting that in Nigeria's case, it is compelled to transfer abroad a sizeable portion of her export revenue for debt repayments. Abeng (2007) regrets that Nigeria's reserve stock which is a key macroeconomic variable was quite above the threshold but lagged far behind its contemporaries in the OPEC and Asian countries.

Ajayi (2003) notes that managing external debts deserve a very conscientious attention of any government as external debts often have a priority claim on the resources of any nation and that external debt management plays an important role within the overall development strategy of a country as an erratic and uneven debt repayments can undermine long term development strategies. In the light of the foregoing, it is imperative that studies are continuously carried out to review how external debts are accumulated and the management strategies employed by developing economies with the attendant impact on macroeconomic variables. It is therefore against this backdrop that this study is set to appraise the external debts management strategies in developing economies and implications on some selected macroeconomic variables using Nigeria as a case study.

\subsection{Statement of the Problem}

External debts management issues among the developing countries have remained a recurrent discourse among public financial management scholars. This is however, not entirely surprising given its fundamental implications for key economic variables especially for a country such as Nigeria The thinking of most scholars is that either Nigeria's external debts are not deployed in such a manner that will engender the much needed economic development or the debts are contracted under very strangulating lending conditions such that the proceeds are well eroded before they can support real economic development.

In their study, Omotola and Saliu (2009) postulate that the collective debts of Africa represents a massive non-judicious utilization of its huge resource base and the failure of policy measures targeted at the management of those resources are evident. Arikawe (2003) argues that sovereign debts problems have been a major public policy issue since World War II including the treatment of debts related to war as the cost of paying interest on the government's debt is very high. Nigeria's debt stock rose at an average rate of $17 \%$ per annum between 1982 and 1994, which implies that Nigeria's stock of External Debts increased by a factor of $33 \%$ in 22 years aside from domestic debts, Iyoha (1997).

Mkadawire (1996) submits that endowed with large high grade oil, one would have expected Nigeria to rank among the richest countries in the world. Soludo (2004) argues that Nigeria when compared with other African countries like Ghana and Latin American especially Brazil, which are comparable to Nigeria in most respects, the pace of economic development in Nigeria has been very slow compared to the volume of its external debts and other resources. He further argues that while Nigeria \$300b fro oil exports since the mid 1970'S, but its per capital income is $20 \%$ than what it was in 1975 regretting that the country has become more indebted with the debt amounting to $70 \%$ of GDP as it has difficulty in servicing its debt.

However, Nwankwo (2011) claims that Nigeria External Debt level has remained within an acceptable limit when compared against international threshold. In a swift response, the leader of the minority in the senate, Gbajamila (2012) decried Nigeria's External debt profile in December, 2011 stating that it cannot support sustainable growth and development. He warned that the economy should not be allowed to retrogress into the deep debt-overhang days. Metu (2012) argues that the Nigeria's External debt profile as at 2011 was nothing to worry about as it has been within the international threshold of $30 \%$ as it stood at $18 \%$. Beyond the figures, scholars are of the view that external debts should not only be measured by the so-called international threshold but should be benchmarked in an all encompassing way to ascertain its actual implications on the welfare and 
standard of living of Nigerian using specific economic indices. In view of the above, this paper is set to appraise external debts management strategies and its impact on key economic variables of developing economies using Nigeria as a case study.

\subsection{Objectives of the Study}

The broad objective of this study is to evaluate External Debts Management Strategies in Nigeria in order to ascertain the impact on the growing economy using some economic variables of Nigeria. The study will specifically:

(1) Determine if there is any relationship between External Debts and Gross Domestic Products (GDP).

(2) Ascertain if there is any relationship between External Debts and Capital Expenditure.

(3) Determine if there is any relationship between External Debts and External Reserves.

(4) Assess if there is any relationship between External Debts and Nigeria's Exports.

\subsection{Research Questions}

In order to achieve the set objectives, the following research questions are formulated to guide this study:

(1) To what extent have Nigeria's External Debts affected Gross Domestic Product (GDP)?

(2) How has Nigeria's External Debts impacted Capital Expenditure?

(3) To what extent have Nigeria's External Debts affected the nation's External Reserves?

(4) To what extent have External Debts affected Nigeria's Export?

\subsection{Research Hypotheses}

The following Null Hypotheses are formulated for this study:

(1) There is no significant relationship between Nigeria's External Debts and Gross Domestic Product (GDP).

(2) Nigeria's Capital Expenditure has not been significantly affected by the external debt stock of Nigeria.

(3) There is no significant relationship between the Nigeria's External Debts and External Reserves.

(4) Nigeria's Exports has not been significantly impacted by the External Debts stock.

\section{Review of Related Literature}

\subsection{External Debt Management and Macroeconomic Performance of Nigeria}

\subsubsection{Empirical Reviews}

Ordinarily, external debts accumulation should impact positively on the key economic indices of any economy. Most studies have however rather revealed a negative correlation between external debt in Nigeria and some economic variables. Enyiuche and Obiefuna (2011) studied the impact of External Debt on the Economic Growth of Nigeria; adopting a content analysis and using GDP, unemployment and consumption as variables, performed an Ordinary and Multiple Regression found out that there exists a significant relationship between external debts and the macro economic variables.

The study further reveals an inverse relationship between external debts overhang measures, other measures of debt, and investment and also a high significance of the debt overhang estimated the high explanatory variables. It study shows reveals that foreign loans into Nigeria were wastefully misappropriated due to the monumental corruption and misappropriation of funds thereby leading to adverse poverty, unemployment and other related vices. They study recommends that debt rescheduling, collective unilateral repudiation of external debts by debtor countries, debt service payments, increase in non-oil export policy drive and accountability to check corruption and fight misappropriation.

Iyoha (1997) in a study on "Nigeria External Debt Overhang" found out that Nigeria External Debt stock rose at an average of $17 \%$ per annum between 1982 and 1994. The study further revealed that excessive high stock of external debt depresses Nigeria's investments and lower the rate of economic growth. It therefore recommends a drastic reduction in external loans and diversification of Nigerian economy.

Leung (2001) investigates "the long term and short term causes of indebtedness" using 92 developing countries with period spanning 1984-1993. The result reveals that growth rate of GDP, Net Exports and GNP per capital negatively affect the level of indebtedness while size of the economy has no effect on the country's overall indebtedness.

In a related study, Sama and Fonchamnyo (2011) using an unbalanced panel of sixty (60) low income countries, 
covering Sub-Saharan Africa, Asia, Latin America and the Middle East, covering the periods 1980-2008. A GMM System Estimator proposed by Arellano and Baver (1995) which combines regression in differences with regressions in levels was used in the analysis. The regression results show that external debt is persistent and that more developing economies accumulate more debts that developed ones over time. The study also reveals that external debts relief measures that are focused on debt rescheduling are not effective in reducing external debts in Low Income Countries depicting need to offer a onetime debt relief package, since debt rescheduling rather increases the stock of debt as opposed to reducing it.

Edo (2002), using data from 1980-1999 to study "Debt Problems in Nigeria and Morroco" found out that fiscal expenditure, balance of payment difficulties and high global interest rates are fundamental factors that explained the debt problems in those countries.

In another study conducted on Ghana titled "Ghana: The Burden of Debt Service Payment under Structural Adjustment". Osei (1995) doing content analysis of the country's profile and data between 1983-1990. The variables studied were Debt to Export ratio; Debt to GDP ratio, Terms of Trade, Investment-Debt ratio asserts that there was a negative correlation between debt stock and the variables studied. He also found that external debts represent a major constraint to the country's economic performance. He advocates that Ghana should pursue further internal reforms to increase domestic savings and fiscal reforms that would increase government revenue so as to minimize its dependence on types of financing that are detrimental to economic health.

\subsubsection{Theoretical Framework}

The impact of External Debts on economic indices of Nigeria can be explained by some known models. Harnod Domar Model which indicates that growth is determined by resources available from both domestic and foreign savings from investments. This model states that when capital inflows fall below interest payments on external debts, foreign savings reveal negative and resulting in low growth as suggested by the standard savings in investment model.

The T-Gap Model is also relevant to this study. The model indicates that the foreign exchange for critical imported inputs and capital goods may be required for development while decreasing net foreign exchange availability is capable of showing growth through lower investments. (World Bank Report, 1990).

Osei (1995) submits that debt problems have been incorporated into models commonly referred to as Growth-Cum-Debt Model. This model was developed to address issues relating to debt sustainability thus stressing how and how far debts affects the growth prosperity of debtor countries.

Authors like Avramovic (1964); King (1968) and Solomon (1977) studies were based on making judgments on debt capacity of developing countries in the context of Harrod-Domar Growth Model. This model emphasis how debt situation evolve over time.

Dhonle (1979), Loser (1977), Naggy (1978) Feder and Just (1977) examined the circumstances under which countries experience debt servicing difficulties. They however, emphasized on external performance of the debtor economy in relation to debt service claims. However, authors such as Weiss (1981), Feder, and Ross (1982), Sach and Cohan (1982) examined factors that influenced lending behaviour, Cohan (1985) Solis and Zedelo (1985) and Van Wyenbergen (1989) related foreign indebtedness to long term growth.

\subsubsection{Conceptual Framework}

\subsubsection{External Debts in Nigeria: A Historical Perspective}

Nigeria external debts can be traced to 1958 when the country first borrowed the sum of US $\$ 28$ for railways construction. Since then, a number of external debts has been contracted with the total external debts outstanding remaining as low throughout the 1960's and 1970's. This was however followed by huge external borrowings in the mid 1980's to finance large capital projects for economic development in the face of dwindling oil revenues occasioned by the glut in the international oil market. The level of external debts stock worsened primarily due to rise in interests rates and recapitalization of the accrued interests on loans. The situation became more aggravated with the entry of state governments into the external loans contractual obligations with many of the loan having unfavourable terms and indeed mismanaged. Consequently, the total debts stock grew rapidly from less than US\$1.0 billion in 1970 to US\$18.5 billion in 1985 and further to US\$34.1billion in 1995 . It however declined to US $\$ 30.9$ billion in 2002 before rising to US\$32.9billion in 2003 and subsequently to US $\$ 35.9$ billion in 2004. Nigeria however made a cumulative debt service payment of about US\$37 billion to all the external creditors between 1985-2004 (Central Bank of Nigeria, 2005 Annual Reports and Accounts)

In 1986, the country had recognised that the debt profile was unsustainable and thus began round of negotiations 
with the Paris Club and other external creditor group to address its precarious debts situation. During that period, Nigeria was able to secure debt restructuring with the last in 2000. A major outcome of that effort was the reaching of restructuring agreement with the Paris Club in December, 2000 based on Houston Terms. Under this term was a debt restructuring package for lower/middle income countries with per capital income of between US\$785.0 and US\$3,125. In that process, Nigeria rescheduled about US\$21.4 billion Paris Club debts for 18-20 years period (Central Bank of Nigeria Annual Reports and Accounts, 2005).

Also the Official Development Agency (ODA) credits were rescheduled to over 18years at market based interest rates with a 3 years grace period. Nigeria's external debt stock continued to accumulate as Holterm only allowed for a deferral payment with no provision for actual debts reduction by 2004. By 29th June 2005, Nigeria had secured a major breakthrough with Paris Club agreement to grant Nigeria an International Development Assistance Only status which was supportive of debt relief struggles. This followed an agreement reached to cancel $60 \%$ or US $\$ 18$ billion. Nigeria had owed the Paris club a total sum of US $\$ 30.85$ billion constituting of principal of US $\$ 25.20 \mathrm{~b}$ and arrears of US $\$ 5.65$ billion. The agreement involved a debt reduction under the Naples terms on eligible debts and a buy-back at market related discount on the remaining eligible debts after reduction and was to be implemented in two phases conditional on the implementation of a comprehensive economic reform programme under the policy support instrument.

Following the signing of an IMF stand-by agreement in August 2000, Nigeria received a $\$ 1$ billion credit from the IMF, both contingents on economic reforms. Nigeria pulled out of its IMF program in April 2002, after failing to meet spending and exchange rate targets, making it ineligible for additional debt forgiveness from the Paris Club. In November 2005, the Federal Government of Nigeria won Paris Club approval for a debt-relief deal that eliminated $\$ 18$ billion of debt in exchange for $\$ 12$ billion in payments-a total package worth $\$ 30$ billion of Nigeria's total $\$ 37$ billion external debt, (Index Mundi, 2012).

\subsubsection{Nature of Nigeria's External Debts}

External Public Debt is the aggregate of all claims against the government of a country held by private or public sector of a foreign economy. It may be interest or non-interest bearing including bank held debts and government currency less any claims held by the government against such foreign creditors,Anyanwu (1993). Nigeria has exited about $\$ 18$ billion worth of debt in 2005. These loans were mainly from Paris and London Club of creditors. However, Nigeria's total external debt stock as at December 31, 2011 stood at US\$5.76b. The nature of Nigeria debt for the purposes of this study is classified according to the type of creditors. The key creditors to Nigerian are categorized as follows:

\section{(a) The Paris Club:}

The Paris Club of creditors had remained Nigerians major creditor. Their debts are government-to-government credits or market-based term loans which were guaranteed by various Export Credit Agencies of the creditor countries. The Paris Club is a cartel of creditor countries that provides an informal forum where countries experiencing difficulties in paying their official debt meet with the creditors to reschedule the debts. Nigeria had however exited the Paris Club debts through the debt cancellation of US\$18b it granted Nigeria in 2006 and the subsequent payment of US\$12b.

\section{(b) London Club Debts (Par Bonds):}

The London Club is a group of commercial banks that join together to negotiate the restructuring of their claims against debtor countries. London Club debts are arrears of commercial bank term loans. They also include some arrears of letters of credit, bills for collection, open accounts, dividends, airline remittances etc. The debts were consolidated in 1991 and amounted to US\$5,437 billion. Out of the stock, the term loans contracted by FGN and the arrears of the non-term loan components were bought-back in January, 1992.

\section{(c) Multilateral Debts:}

Multilateral Debts make up the second category of debts owed by Nigeria. These are project loans owed to multilateral financial institutions (e.g., the World Bank Group, the African Development Bank Group, the European Investment Bank Group, IFAD, and ECOWAS Fund) by federal and state governments and their agencies. The total amount owed to multilateral institutions as at December 31, 2011 was US\$4,568.92million.

\section{(d) Non Paris Club (Bilateral Debts)}

These are debts owed to other countries, which are not members of the Paris Club and creditors resident in Paris Club countries but whose debts are not insured by the Export Credit Agencies. The amount owed to this category of creditors was US\$547.66 as at 31st December, 2011. 
(e) International Capital Market: Nigeria has in 2011 raised a capital through the issue of Euro bond amounting to US\$500 million.

\subsubsection{Causes of External Debts Accumulation in Nigeria}

Omoruyi (2007) identifies the key causes of external debts by Nigeria to include:

(i) Weak Resource Mobilization vis-a-vis Heavy Debt Stock to Exports Ratio: Nigeria has experienced poor export performance because of weak terms of trade, low tax efforts and poor savings arising largely from inefficient revenue collection machinery. At the same time there has been unbridled growth of government expenditure and insignificant foreign exchange inflow in form of direct investments.

(ii) Sources of Borrowings (Issues of concessionality and seniority of Loans): Considering the economic, social and environmental decline in most Third World countries especially those of Sub-Saharans Africa, the need to source foreign borrowings on concessional terms. This has often formed an attraction for these debtor countries who in turn find it difficult to make repayments as contracted.

(iii) Currency Composition of External Borrowings: The currency in which foreign borrowings are drawn-down is important for any country seeking external financing. This has been the case of Nigeria and other developing economies that have their credits denominated in the very strong dollar against the weak naira and so on.

(iv) Problem of bunching of maturities: The difficulty of getting borrowings to be stratified by diversifying markets and instruments so as to prolong maturities while narrowing down the spreads. Third World debtor countries have had difficulties achieving this strategy with the result that most of the loans fall due for repayment about the same time, exerting cash flow pressure far beyond the debt servicing capabilities of debtor countries.

(v) Poor Debt Monitoring: Most times the actual government obligations to its creditors are not concise. This is evident in the discordant figures of external debt figures in the form of actual principal borrowings, repayments and even outstanding being produced by the agencies of government in charge of managing debts. This results in some debts not being articulated at the appropriate times leading to penalties of interests arrears being charged on them.

(vi) Inefficient Management of Funds from External Borrowings: More often than not governments of developing countries borrow to finance white elephant projects. These projects often fail the self sustainability test. The loans in most cases are diverted to financing consumption projects and not the real economic sectors/capital projects that would engender economic growth. Arowoh (2010) submits that poor economic management at the domestic front in the form of wasteful unproductive expenditure in addition to the mismanagement of borrowed funds by inefficient public enterprise were a major feature of Nigeria.

(vii) Multi-Year Rescheduling: Multi-year rescheduling is often referred to as block rescheduling, that is, consolidating debt falling due in several years into a single sum. Creditor country governments favour year-by-year rescheduling while debtor governments appreciate the flexibility of annual rescheduling but worry that short consolidation periods also mean short planning horizons and the need for virtually continuous negotiations.

(viii) Fluctuating interest rates: Under the Paris Club rescheduling, the debtor country has to negotiate bilaterally with each creditor country on the interest rate to be charged on the rescheduled debt as the rate varies from country to country.

Ajayi and Kham (2000) also identified some of the causes of external debt accumulation in developing countries to include what they tagged:

- The overly attempts of many government to speed up growth prompted by international creditors who were also overly generous;

- Impact of oil price shocks, rising real interest rates brought about by the restrictive monetary policy of developing countries, declining terms of trade;

- Liberal lending policies of foreign commercial banks, successive administration macroeconomic policy errors, penchant for investing in white elephant projects and domestic macroeconomic policy errors in the form of fiscal irresponsibility and exchange rate misalignment.

\subsubsection{External Debt Management in Nigeria}

Prior to year 2000, the task of external debt management in Nigeria was coordinated by the Central Bank of Nigeria. However, establishment of the Debt Management Office in the year 2000 saw the role of external debt 
management and indeed other debts transferred, to be managed and infact coordinate Nigerian's debt which was hitherto done by myriads of establishment in an uncordinated fashion.

External debt management entails is the process of providing for payment of interests, arranging the refinancing of bonds and debts that are maturing (Okwo,2010). She further notes that the main objective of external debt management policy is to achieve external finance without affecting negatively the macroeconomic objectives and stability of balance of payment. External loans when productively utilized should accelerate the pace economic development.

\subsubsection{Objectives and Guidelines to External Borrowings in Nigeria}

According to Adepoju et al (2007), in the 1980's, the management of external debts was the responsibilty of the Central Bank of Nigeria. Although the debt managent strategies and measures varied from time to time, the following has guided external borrowing (Anyanwu, 1997):

i. Economic sector projects should have positive internal rate of return as high as the cost of borrowings.

ii. Social services or infrastructure would be ranked on the basis of their cost/benefits ratios.

iii. Projects to be financed with external loans should include loan acquisition development and retirement schedule.

iv. External loans for private and public sector projects with quick returns should be sourced from the international capital market while loan for social services could be sourced from concessional financial institutions.

iv. Borrowing by state government, parastatals and private agencies should receive approval of the federal government to ensure that borrowing conforms with national objectives.

v. State governments borrowing proposals should be submitted to Federal Ministry of Finance and the CBN for consideration before they are incorporated in the final public sector borrowingfor the annual budget.

vi. State government and other government agency should as well as federal parastatals should service their debts through the Foreign Exchange Market and inform Federal Ministry of Finance for record purposes.

vii. For loans on-lent by the federal government, to state government, the Federal Ministry of Finance would make due payments and deduct the full amount at source from their statutory allocations.

\subsubsection{Nigeria's External Debt Management Strategies}

Nigeria has managed its external through the following ways:

(1) Placing outright embargo on new loans: the imposition was to check the escalation of the level of total debt stock and minimize the problems of additional debt burden.The policy was applied by intermettently fixing a ceiling to what the government both state and federal government can borrow at any given period. For instance in 1984 state governments were banned outrightly from contracting external debts. Occassionally too, the federal government has fixed the maximum level of debt commitment for the tiers of government.

(2) Limit on Debt Service Payments: This measure involves setting aside a proportion of export earnings to meet debt service obligation to allow for internal development. In 1980 for instance the state government were directed limit its debt servicing to a maximum of $10 \%$ of its total revenue and the federal government $30 \%$.

(3) Debt Restructuring; the practice entails conversion of an existing debt into another category of debt done through refinancing, buy back, issuance of collaterized bonds and the provision of new money.

- Debt Refinancing- this strategy proffers an arrangement in the the government procures new loan (especially short term trade debt) to pay-off an existing debt. However, a negotiation is held with the new creditor with repayment specified in the new agreement.the first refinancing arrangement was in july, 1983 preceeded by another one in september the same year during which US\$2.1billion, with applicable interest rate of $1.5 \%$ above the London Inter Bank Offer Rate trade arrears were refinanced.By 1986, Nigeria paid off and exited the debt and has continued to utilise the tool to reduce its debt burden.

- Debt Resheduling- this measure involves changing of maturity structure of the debt. Debt is usually spread over a longer period until it is financially liquidated. 
- Debt buy back, collaterization and new money option- the buy back arrangement implies the offer of substantial discount to pay off an existing debt. Nwankwo, 2011 commenting on the huge debt stock, saying: "Between 2004 and 2006, the implementation of the exit from Paris Club was completed such that Nigeria was forgiven 60 per cent of the $\$ 30$ billion foreign external debt, and $\$ 18$ billion was written off while $\$ 12$ billion was paid and so we completely exited.

(4). Debt Conversion: Debt conversion as a mechanism was introduced in July.1988 and entails the exchange of monetary instruments like promisory notes for tangible assets and other financial instruments. It is a mechanism for reducing a country's debt burden by changing the character of the debt. It can be in the form of debt for equity or debt for cash. The country through this process either sold its external debt instument for as domestic debt or equity participation in domestic enterprises. A whooping sum of USD908.3 million debt relieve occured between 1988-1995. Within the period Nigeria had a discount of USD423.6 million. It also received a commission of USD11.6 million.

\subsubsection{Limitations/Challenges to Effective External Debts Management in Nigeria}

Various scholars have identified the major limitations to effective debts management in Nigeria to include:

- Inability to generate sufficient foreign exchange through export earnings, Bafour (1995).

- Wrong macroeconomic policies: Debt management has suffered some set back in Nigeria due to some wrong macroeconomic policies which has encouraged fiscal irresponsibility and exchange rate misalignment (Khan \& Knight, 1983; Muns, 1984).

- Illiquidity Problem: Lack of liquidity occurs when a country does not have enough cash on hand to pay current obligations (Eaton \& Taylor, 1986). The solvency issue relates to whether the value of a country's liabilities exceeds the ability to pay at any time. A country is insolvent when it is incapable of servicing its debts in the long run (Ajayi,1991).

- Another fundamental issue is the lack of accurate data base depicting the actual external debt balances (Nwankwo, 2012): Some of the developing economies lack accurate data base to show the outstanding debts and other information on repayment shedules on the loans with substantive amount of the debt being accumulation from outstanding loans uncaptured.

- Policies that deter savings, such as negative real interest rates, which in turn reduce investment and encourage capital flight: (Tanzi and Blejer, 1984) note that often long-term projects are financed with short-term credits leading to a situation where repayments get due before projects are completed.

- Volatility of petroleum produce and other commodities that form the main base of foreign exchange leading to a deterioriation, shocks, terms of trade (Greene \& Khan, 1990) and rising foreign interest rates (Krumm, 1985).

- Mismanagement and misappropriation of funds:Most of the developing countries especially Nigeria have a huge chunk of their revenue fizelled away through mismanagement and mismanagement. These funds would have been employed in its debt repayments. The various anti-corruption agencies have not succeeded in curbing this trend as a slow pace of geting justice against perpetrators.

\section{Research Methodology}

\subsection{Research Design}

Since this study is on the external debt accumulation and management strategies of developing economies using Nigeria as case, we used a conceptual and descriptive design approach. The research design is Non-Experimental. Non-experimental design is ideal for a study of this nature as it is concerned with assessment of the impact of external debts accumulation and management strategies on economic variables, (Azuka, 2011). It will also involve the content analysis of the annual reports and accounts of the Central Bank of Nigeria, Debt Management Office releases and Bulletins of Accountant General of the Federation to enable inferences to be drawn.

\subsection{Population/Sample Size}

The study will centre on Nigerian economy with particular emphasis on its External Debts and their management strategies and specific effects on GDP, Capital Expenditure, External Reserves and Exports. The study covers a ten year period spanning 2002-2011. The population of this work will comprise all the external debts statistics of this period. The researchers chose to study ten years 2002 to 2011 as this period constituted a reasonable period that presents Nigeria's pre-debts and post debts-relief era. For the purposes of this study, the population will be 
the same as the sample.

\subsection{Sources of Data}

The sources of data for the research shall be secondary sources. These secondary data will be sourced from relevant textbooks, journals from libraries and the internet. However, the quantitative data for analysis shall be sourced from the annual reports/statistical releases of the Debt Management Offices, the Central Banks of Nigeria, the Office of the Accountant General of the Federation and Ministry of Finance.

\subsection{Tools for Data Analysis}

The hypotheses of the study will be tested using the correlation and simple linear regression techniques to determine the relationship between external debts stock and some economic variables such as GDP, Capital Expenditure, External Reserves and Exports.

\subsection{Model Specification}

\subsubsection{Linear Regression}

To analyse the respective relationships defined in preceding sections, simple linear regressions analysis will be performed based on the following general models as applied in previous studies.

These models will be used to test the hypotheses based on the general linear function model as follows:

$$
Y=a+b x
$$

This model is modified a little bit as follows for the different hypotheses.

\section{Hypothesis one:}

$\mathrm{H}_{0}$ : There is no significant and positive relationship between Nigeria's External Debts and Gross Domestic Product (GDP).

$\mathrm{H}_{1}$ : There is significant and positive relationship between Nigeria's External Debts and Gross Domestic Product (GDP).

Where:

$$
G D P_{t}=\beta_{O}+\beta_{l} E X T D B T_{t-1}
$$

$\mathrm{GDP}_{\mathrm{t}}=$ Gross Domestic Product;

$\beta_{O}=\mathrm{a}$ constant;

$\beta_{1}=$ Coefficient of the independent variable;

$\mathrm{EXTDBT}_{\mathrm{t}-1}=$ External Debts size;

This model will be used to determine the relationship between the Gross Domestic Product and External Debt size.

\section{Hypothesis Two:}

$\mathrm{H}_{0}$ : Nigeria's Capital Expenditure has not been significantly and positively affected by the external debt stock of Nigeria.

$\mathrm{H}_{1}$ : Nigeria's Capital Expenditure has been significantly and positively affected by the external debt stock of Nigeria..

$$
\text { CAPExpt }=\beta_{O}+\beta_{1} E X T D B T_{t-1}
$$

Where:

$\mathrm{R} / \mathrm{E}_{\mathrm{t}}=$ the country's capital expenditure;

$\beta_{O}=$ a constant;

$\beta_{1}=$ Coefficient of the independent variable;

$\mathrm{CAPExp}_{\mathrm{t}-1}=$ External Debts.

This model will be used to determine the relationship between the country's capital expenditure and the external debts.

\section{Hypothesis Three:}

$\mathrm{H}_{0}$ : There is no significant and positive relationship between the Nigeria's External Debts and External Reserves. 
$\mathrm{H}_{1}$ : There is significant and positive relationship between the Nigeria's External Debts and External Reserves.

$$
\text { EXTRES }_{t}=\beta_{O^{+}} \beta_{1} E X T D B T_{-1}
$$

Where:

EXTRES $_{\mathrm{t}}=$ the external reserve, $\mathrm{t}$

$\beta_{O}=\mathrm{a}$ constant;

$\beta_{1}=$ Coefficient of the independent variable;

EXTDBT $_{\mathrm{t}-1}=$ External Debt.

This model will be used to determine the relationship between a country's external debts and External Reserves.

\section{Hypothesis Four:}

$\mathrm{H}_{0}$ : Nigeria's Exports has not been significantly and positively impacted by the External Debt stock.

$\mathrm{H}_{1}$ : Nigeria's Exports has been significantly and positively impacted by the External Debt stock.

$$
E X T P_{t}=\beta_{O^{+}} \beta_{1} E X T D B T_{-1}
$$

Where:

$\mathrm{EXPT}_{\mathrm{t}}=$ the export, $\mathrm{t}$;

$\beta_{O}=$ a constant;

$\beta_{1}=$ Coefficient of the independent variable;

EXTDBT $_{\mathrm{t}-1}=$ External Debt.

This model will be used to determine the relationship between a country's external debt and exports.

\subsection{Definition of Independent Variables}

(1) Gross Domestic Product (GDP): The Gross Domestic Product is the aggregate value of goods and services produced in a country in a given period irrespective of the national that produced it.It equals the total income of everyone in the economy and the total expenditure on the economy's output of goods and services. According to Ugwuanyi and Onyeka (2012) GDP is the guage of economic performance because it measures something people incomes. They further note that an economy with a large output of goods and services can better satisfy the demands of households, firms and government.

(2) Capital Expenditure (CAPEXP): These are the investments which the government of any country makes in order to execute projects/infrastructure that will grow its real sector that could engender economic growth and development. Those expenses made in the procurement of assets in the form expenditure.

(3) External Reserves (EXTRES): The International Monetary fund (1993) defined external reserve at the assets that are readily available to and controlled by monetary authorities for direct financing of payments imbalances through intervention in the exchange markets to affect the currency exchange rate and / or for other purposes. Hussian (2002) submits that the gradual accumulation of reserves through non-debt creating means to a sufficiently comfortable level avoids panic in the market and precludes the need for contracting additional debts for the country.

Exports (EXPT): This is the value of the aggregate goods and services sent from a resident to a non-resident. The export of any nation is a major source of foreign exchange.

\section{Presentation and Analysis of Data}

\subsection{Presentation of Data}

This chapter presents, analy and interpretes data that are extracted from the Nigeria economic profile and statistics from Debts Management Offices, Central Bank and Ministry of Finance. The data to be presented and used for analysis are secondary data. They were sourced from relevant textbooks, journals, and the internet. However, the quantitative data for analysis shall be sourced from the annual reports/ statistical releases of the Debts Management Office, the Central Bank of Nigeria and the Office of the Accountant General of the Federation/Ministry of Finance. Where necessary the researchers have converted the figures to Dollars using the average rate prevailing in the year under study. 
Table 1. Nigeria's debt stock, gross domestic product, capital expenditure, external reserves and exports

\begin{tabular}{|c|c|c|c|c|c|}
\hline Year/Variables & $\begin{array}{l}\text { External Debts } \\
\left(\#^{\prime} m\right)\end{array}$ & $\begin{array}{l}\text { GDP } \\
\text { (N'm) }\end{array}$ & $\begin{array}{l}\text { Capital } \\
\text { (N'm) }\end{array}$ & $\begin{array}{l}\text { External } \\
\text { Expenditure }\end{array}$ & $\begin{array}{l}\text { Exports } \\
\text { Reserve (\#'m) }\end{array}$ \\
\hline 2011 & $896,832.65$ & $37,543,654.70$ & $918,548.29$ & $5,021,633.20$ & $14,321,453.40$ \\
\hline 2010 & $689,845.30$ & $33,984,754.13$ & $883,870.00$ & $4,842,486.80$ & $11,532,022.70$ \\
\hline 2009 & $590,441.08$ & $24,794,238.66$ & $1,152,796.50$ & $6,310,754.30$ & $8,356,385.60$ \\
\hline 2008 & $493,180.22$ & $24,296,329.29$ & $960,890.01$ & $6,282,137.70$ & $10,161,490.10$ \\
\hline 2007 & $431,079.85$ & $20,657,317.67$ & $759,281.20$ & $6,459,250.30$ & $8,309,758.30$ \\
\hline 2006 & $451,461.70$ & $18,564,594.74$ & $552,358.80$ & $5,441,637.70$ & $7,324,680.60$ \\
\hline 2005 & $2,695,072.20$ & $14,572,239.12$ & $519,470.00$ & $3,732,828.00$ & $7,246,534.80$ \\
\hline 2004 & $4,890,269.90$ & $11,411,066.91$ & $351,250.00$ & $2,252,644.00$ & $4,602,781.50$ \\
\hline 2003 & $4,478,329.30$ & $8,487,031.57$ & $241,688.30$ & $1,065,093.00$ & $3,087,886.40$ \\
\hline 2002 & $3,932,884.80$ & $6,912,381.25$ & $321,378.10$ & $1,013,514.00$ & $1,744,177.70$ \\
\hline
\end{tabular}

Source: Debt Management Office, Central Bank of Nigeria and Office of the Accountant General of the Federation.

\subsection{Analysis of Data}

Hypothesis 1: (Null)

H0: There is no significant and positive relationship between the Nigeria's External Debts stock and GDP.

Table 2. The regression result of volume of external debts and GDP

Panel A. Summary output

\begin{tabular}{lc}
\hline \multicolumn{2}{c}{ Regression Statistics } \\
\hline Multiple R & 0.771177192217078 \\
R Square & 0.594714261795816 \\
Adjusted R Square & 0.544053544520293 \\
Standard Error & 6952743.39411032 \\
Observations & 10 \\
\hline
\end{tabular}

Panel B. ANOVA

\begin{tabular}{lccccc}
\hline ANOVA & $D f$ & $S S$ & $M S$ & $F$ & Significance $F$ \\
\hline Regression & 1 & 567478511898435 & 567478511898435 & 11.7391599207214 & 0.00900457020478814 \\
Residual & 8 & 386725125634758 & 48340640704344.7 & & \\
Total & 9 & 954203637533193 & & & \\
\hline
\end{tabular}

Panel C.

\begin{tabular}{ccccccccc}
\hline & Coefficients & $\begin{array}{c}\text { Standard } \\
\text { Error }\end{array}$ & \multirow{2}{*}{ Stat } & P-value & $\begin{array}{c}\text { Lower } \\
95 \%\end{array}$ & Upper 95\% & $\begin{array}{c}\text { Lower } \\
95.0 \%\end{array}$ & $\begin{array}{c}\text { Upper } \\
95.0 \%\end{array}$ \\
\hline \multirow{2}{*}{ Intercept } & 28521234.57 & 3292886. & 8.66146807 & 0.000024543 & 20927823 & 36114645.3 & 20927823. & 36114645. \\
& 81254 & 87893905 & 548848 & 2633622994 & .8248056 & 314453 & 8248056 & 3314453 \\
X Variable 1 & -4.296231630 & 1.253918 & -3.4262457 & 0.009004570 & -7.187772 & -1.4046912 & -7.187772 & -1.404691 \\
& 12416 & 12117997 & 4727519 & 20478814 & 00038382 & 5986449 & 00038382 & 25986449 \\
\hline
\end{tabular}

\section{Hypothesis iv: (Null)}

H0: There is no significant and positive relationship between the Nigeria's External Debts accumulations and its Export. 
Table 3. The regression result of external debts stock and total exports

Panel A. Summary output

\begin{tabular}{lc}
\hline \multicolumn{2}{c}{ Regression Statistics } \\
\hline Multiple R & 0.779774268206555 \\
R Square & 0.608047909357069 \\
Adjusted R Square & 0.559053898026702 \\
Standard Error & 2532184.65889057 \\
Observations & 10 \\
\hline
\end{tabular}

Panel B. ANOVA

\begin{tabular}{lccccc}
\hline ANOVA & $D f$ & $S S$ & $M S$ & $F$ & Significance $F$ \\
\hline Regression & 1 & 79576630861209.5 & 79576630861209.5 & 12.4106578099312 & 0.0078129599020685 \\
Residual & 8 & 51295673173766 & 6411959146720.75 & & \\
Total & 9 & 130872304034975 & & & \\
\hline
\end{tabular}

Panel C.

\begin{tabular}{ccccccccc}
\hline & Coefficients & $\begin{array}{c}\text { Standard } \\
\text { Error }\end{array}$ & t Stat & P-value & $\begin{array}{c}\text { Lower } \\
95 \%\end{array}$ & Upper 95\% & $\begin{array}{c}\text { Lower } \\
95.0 \%\end{array}$ & $\begin{array}{c}\text { Upper } \\
95.0 \%\end{array}$ \\
\hline \multirow{2}{*}{ Intercept } & 10804850.8 & 1199267.27 & 9.00954362 & 0.000018387 & 8039335. & 13570366.1 & 8039335.5 & 13570366. \\
& 505986 & 705423 & 495288 & 3434704216 & 55278113 & 48416 & 5278113 & 148416 \\
X Variable 1 & -1.6088136 & 0.45667617 & 3.52287635 & 0.007812959 & -2.661910 & -0.5557165 & -2.661910 & -0.555716 \\
& 8392006 & 0825817 & 461865 & 90206848 & 8214236 & 4641651 & 8214236 & 54641651 \\
\hline
\end{tabular}

\subsection{Discussion of Analysis}

Table 1 shows the result of the regression analysis conducted to determine the relationship between the External Debts stock and Gross Domestic Product (GDP) in Nigeria. The correlation coefficient of (0.77) indicates that there is a high positive correlation between the volume of External Debts and the Gross Domestic Product (GDP) in Nigeria. The $\mathrm{R}^{2}$ value of $(0.71)$ indicates that $71 \%$ of the variations in Gross Domestic Product (GDP) is explained by the stock of External Debts accumulated and that a unit of naira increase in external debts will correspondingly increase the (GDP) in Nigeria. The results further showed that External Debts has a very strong positive and significant relationship at $1 \%$ significant level with the Gross Domestic Product (GDP). However, the Analysis of Variance reveals that External Debts has a negative relationship with Gross Domestic Product (GDP) in Nigeria. From that result, the Gross Domestic Product (GDP) can be forecast using the following equation: GDP $=28,521,234.58-4.296 \mathrm{x}$.

Table 2 shows the result of the regression analysis conducted to determine the relationship between external debts and capital expenditure of Nigeria. The correlation coefficient of $(0.84)$ indicates that there is a high positive correlation between external debts and the capital expenditure. The $\mathrm{R}^{2}$ value of $(0.71)$ indicates that $71 \%$ of the variations in capital expenditure in Nigeria, is explained by the amount generated from external debts and that a unit of naira increase in the amount generated through external debts will correspondingly increase the capital expenditure of Nigeria. The result further showed that external debts have very strong positive and significant relationship at $1 \%$ significant level with the capital expenditure of Nigeria. However, the Analysis of Variance reveals that the amount generated through external debts has negative relationship with the capital expenditure in Nigeria. From that result, the capital expenditure of Nigeria can be forecast using the equation: Capital expenditure $=945,561.93-0.14 \mathrm{x}$.

Table 3 shows the result of the regression analysis conducted to determine the relationship between external debts stock and external reserves of Nigeria. The correlation coefficient of (0.94) indicates that there is a high positive correlation between external debt stock and the external reserves. The $\mathrm{R}^{2}$ value of $(0.88)$ indicates that $88 \%$ of the variations in external reserves of Nigeria, is explained by the amount generated from the external debts and that a unit of naira increase in the amount generated through external debts will correspondingly increase its external reserve. The result further showed that external debts have very strong positive and significant relationship at $1 \%$ significant level with the external reserve of Nigeria. However, the Analysis of Variance reveals that the amount generated through external debts is not significant and infact has a negative relationship with its external reserves. 
From that result, the external reserve of Nigeria can be forecast using the following equation: External Reserves $=$ $6,352,646.82-1.08 \mathrm{x}$

Table 3 also shows the result of the regression analysis conducted to determine the relationship between external debts stock and exports of Nigeria. The correlation coefficient of $(0.77)$ indicates that there is a high positive correlation between the amount external debt stock and the exports. The $\mathrm{R}^{2}$ value of $(0.60)$ indicates that $60 \%$ of the variations in exports of Nigeria, is explained by the amount generated from the external debts and that a unit of naira increase in the amount generated through external debts will correspondingly increase the exports of Nigeria. The result further showed that external debts have very strong positive and significant relationship at $1 \%$ significant level with the exports of Nigeria. It further reveals in the Analysis of Variance, that the amount generated through external debts has no significant and infact a negative relationship with its exports. From that result, the exports of Nigeria can be forecast using the following equation:

$$
\text { Exports }=10,804,850.85-1.61 x \text {. }
$$

\section{Summary of Findings, Conclusion and Recommendations}

\subsection{Summary of Findings}

The aim of this study was to empirically evaluate the impact of external debts management strategies on developing economies using Nigeria as case study. The variables studied comprises Gross Domestic Products, Capital Expenditure, External Reserves and Exports. The period studied was ten year spanning, 2002-2011.

Major findings from the study shows:

(1) The first hypothesis shows that there exists a negative relationship between the External Debt stock in Nigeria and its Gross Domestic Product. This result collaborates earlier studies by Enyiuche and Obiefuna (2011); Sama and Fonchamyo (2010); Leung (2001) and Ossei (1995) as they all agreed that external debt accumulated by the developing countries have negatively impacted productivity measured as GDP.

(2) The second hypothesis tested the relationship between External Debt and Capital Expenditure reveals a negative relationship as the External debts that have been accumulated over the years have not positively impacted capital expenditure. This revelation is in line with Enyiuche and Obiefuna (2011); Borenzstein (1986); who noted that External Debts overhang has an inverse effect on public investments/capital expenditure.

(3) The third hypothesis tested the relationship between external debts stock and external reserves and shows a negative relationship between the two variables in Nigeria.

(4) The fourth hypothesis which tested the relationship between External Debt accumulated and export revealed a negative relationship. This collaborates ealier studies by Ossei, (1995); Sama and Fonchamyo (2010); and Leung (2001).

\section{Other findings are of the study are:}

(5) Misappropriation and mismanagement of foreign loans has been a major issue confronting external debts management in Nigeria. Misapplication of debts as most times loans are not deployed to execute projects that engenders growth and development of the real sector for which they were meant for.

(6) Incessant rescheduling of debt rather outright cancellation has compounded the problem as it leads to increase in accumulated principal and interests that are usually capitalized to increase the debt overhang.

\subsection{Conclusions}

External debts and management issues in developing countries have been challenging as it has been exerting especially for countries like Nigeria. Nigeria has in the last decade struggled with managing its external debts but more often than not the country still see itself trapped in the web of very heavy external debts that try to strangle key economic variables of the country instead of boosting country. The country will do more by ensuring that its external debts are managed and directed towards well articulated projects that could engender an encompassing and sustainable economic growth and development.

\subsection{Recommendations}

The research study offers the following recommendations on how external debts accumulations could be managed to ensure better economic performance:

(1) External debts should be tied to projects that are self-sustaining/liquidating. Debts must be contracted to finance projects that can stimulate the real sector. 
(2) The key macroeconomic variables such as GDP, Capital Expenditure, External Reserve and even Exports should always be benchmarked against external debts strategies being implemented.

(3) Debts negotiations should abhor capitalization/compounding of interests. Nigeria should seek multi-year rescheduling rather than year by year basis.

(4.) Nigerian should diversify its economy from a mono-economy dependent on oil to encourage other productive sectors and avoid loans that are tied to market-driven interest rate but rather should opt for fixed interest rate.

(5) Nigeria should devote adequate funds for debt servicing. This would enable the country to accommodate the creditors' requirements. Spending of external credits should be strictly on productive self-liquidating projects in order to grow the real sector while federating units should have a well spelt out policy documents/guidelines to coordinate issues on external debts.

(6) Outright cancellation of external debts should be sought as against rescheduling of loans as rescheduling often lead to capitalization/ compounding of interests that bloat debt balances.

\section{References}

Abeng, M. O. (2007). Foreign exchange reserves accumulation: Implications for Nigerian economy. $C B N$ Bullion Publication, 31(3), 32-50.

Adepoju, A. A. (2007). The effects of external debt management on sustainable economic growth and development: Lessons from Nigeria. http://mpra.ub.uni-muenchen.de/2147

Ajayi, S. I. (1990). Macroeconomic approach to external debt: The case of Nigeria. AERC Research Paper.

Aluko, F., \& Arowolo, D. (2010). Foreign Aid, the Third World's Debt Crisis and the Implication for Economic Development: The Nigerian Experience. African Journal of Political Science and International Relations, 4(4), 120-127. http://www.academicjournals.org/ajpsir

Anang, S., \& Khan, M. (2007). External debt and capital flight in Sub-Saharan Africa. Washington DC: International Monetary Fund.

Anyanwu, J. C. (1997). The Structure of the Nigerian Economy (1960-1997). Onitsha: Janee Education Publishers.

Arikawe, A. (2003). Nigeria and the Highly Indebted Poor Countries (HIPC) Initiative (1). A paper presented to the Joint UNITAR/WAIFEN Sub-regional Workshop on Debt Negotiation and Renegotiation for West Africa Nations Banjul, Gambia; 23: 27200.

Arikawe, A. (2003). Nigeria's external debt management, challenges and initiatives. Paper presented to the Executive Management Seminar organized by the Financial Institutions Training Centre, Kaduna, February, 24-28.

Central Bank of Nigeria. (2002-2011). Annual reports and accounts.

Central Bank of Nigeria. (2002-2011). Statistical bulletins, 21, 98.

Central Intelligence Agency. (2013). http://www.cia.gov/library/publications/the worldfactbook

Debt Management Office. (2011). Nigeria's external debt profile. Abuja: Government Press.

Debt Management Office. (2012). Nigeria 's external debt profile. Abuja: Government Press.

Duru, E. J. C., \& Anang, A. (2006). Domestic debt crisis management in Nigeria: A Re-appraisal. Nigerian Public Administration Review, 1(1), 126-139.

Edo, S. E. (2002). External Debt Problem in Africa: A Comparative Study of Nigeria and Morroco. African Development Bank. http://dx.doi.org/10.1111/1467-8268.00052

Enyiuche, A. C., \& Obiefuna, A. O. (2011). Economic impact of external debt on economic growth of Nigeria. Nigerian Journal of Management Research, 6(1), 66-75.

Iyoha, M. A. (1994). Africa's Debt Problems and Economic Development. Paper presented for the Annual Conference of the Nigerian Economic Society, May.

Iyoha, M. A. (1997). Debt Overhang, Debt Reduction, Investment and Economic Growth in Nigeria. Ibadan: National Centre for Economic and Administration.

Kramer, R. (2005). Pan Africa: G8 Debt Agreement to Benefit 23 African Countries; Separate Deal for Nigeria 
Mooted. http://allafrica.com/\%20stroies

Leung, H. (2001). An empirical investigation in long and short term indebtedness. Retrieved from http://mercury.smu.edu..sg/rsrchpubupload/1184/AnEmpiricalInvestigation.pdf

Mkandawire, T., \& Olukoshi, A. (1996). Between liberalization and oppression: The politics of structural adjustment in Africa. Dakar: CODESRIA Books.

Muhtar, M. (2006). Nigeria's external debt and the economy. DMO Publications. http://majrca.global.com/dmo.gov.ng/debtstategy/extdebstart.htm

Nigeria Economy Profile. (2012). http://www.indexmundi.com/nigeria/economy-profile

Nigerian Economic Society. (2004). Globalization and Africa's economic development. Ibadan: NSE.

Obadan, I. M. (2004). Foreign capital flows and external debts: perspectives on Nigeria and the LDCs Group. Lagos: Broadway Press Limited.

Okonjo-Iweala, N. (2001). Managing Nigeria's debt: International and governance aspects. Paper presented at the International Conference on Nigeria's debt, Abuja May 17.

Okonjo-Iweala, N. (2005). Debt cancellation is necessary for the Reform. Abuja: DMO Publications.

Omoruji, S. E. (1995). Nigeria's debt management control: problems and prospects. Paper presented at the seminar on Macroeconomic Policy for CBN Executive staff, held in Lagos, 15th-19th November.

Omoruyi, S. E. (2004). The Nigerian Debt Crisis and Debt Management Strategies. Lagos, Office of the Debt Management Department, Central Bank of Nigeria.

Omotala, J. S., \& Saliu, H. (2009). Foreign Aid, Debt Relief and Africa's Development: Problems and Prospects. South African Journal of International Affairs. http://dx.doi.org/10.1080/10220460902986180

Osei, B. (1995). Ghana: Burden of Debt Service Payment under Structural Adjustment Programme. African Economic Consortium, Nairobi.

Oyejide, T. A., Soyede, A., \& Kayode, M. O. (1985). Nigeria and the IMF. Ibadan: Heinemann Educational Book Nigeria. Ltd.

Sama, C. M., \& Fonchamnyo, C. D. (2010). The Political Economy of External Debt Accumulation: Empirical Evidence from Low Income Countries. African Journal of Contemporary Issues, 10(2), 1-8.

Soludo, C. C. (2004). Nigeria: National Economic Empowerment and Development Strategy (NEEDS). Abuja: National Planning Commission.

Soludo, C. C. (2008). Financing Imo State towards greatness. Public lecture delivered to mark the one-year anniversary of the Executive Governor of Imo State. Chief Ikedi Ohakim at the Imo Concorde Hotel, Owerri, May 27.

Soludo, C. C. (2009). Financial Globalization and Domestic Monetary Policy: Whither the Economics for the 21st Century? An Inaugural Lecture delivered while marking his 20th Year in Academics Profession at the Convocation Arena of UNN.

The Vanguard Newspapers. (2011). Nigeria debt hits $\$ 6.189$ trillion. Retrieved from http://twitter.com/vanguardngnews

Ugwuanyi, B. U., \& Onyeka,V. N.(2012). Foreign Exchange Volatility and Economic Growth in Nigeria. ESUT Journal of Accountancy, 3(1), 118-124.

Umoren, R. (2001). Economic reforms and Nigeria's political crisis. Ibadan: Spectrum Books Limited. Retrieved from http://www.Nigeria'sDebtcancelledineParisclub-del

Yusufu, T. M. (1996). The Nigerian Economy: Growth without development; Benin Social Series for Africa. University of Benin City, 88-110.

\section{Appendix}

Appendix A. Nigeria External Debt Outstanding by Creditors: 2002-2011 US\$ Million

\begin{tabular}{lllllll}
\hline Creditor Category/ Year & Multi-lateral & Paris Club & London Club & Promissory Notes & Others & Total \\
\hline 2011 & $4,568.92$ & 0.00 & 0.00 & 0.00 & $1,097.66$ & $5,666.58$ \\
2010 & $635,454.90$ & 0.00 & 0.00 & 0.00 & $54,390.41$ & $689,845.30$ \\
\hline
\end{tabular}




\begin{tabular}{lllllll}
\hline 2009 & $524,208.11$ & 0.00 & 0.00 & 0.00 & $66,232.97$ & $590,441.08$ \\
2008 & $420,603.58$ & 0.00 & 0.00 & 0.00 & $72,576.64$ & $493,180.22$ \\
2007 & $363,448.79$ & 0.00 & 0.00 & 0.00 & $67,631.05$ & $431,079.85$ \\
2006 & $332,219.20$ & 0.00 & 0.00 & $64,832.60$ & $54,409.90$ & $451,461.70$ \\
2005 & $330,654.40$ & $2,028,580.10$ & $189,768.40$ & $85,526.70$ & $60,542.60$ & $2,695,072.20$ \\
2004 & $384,248.70$ & $4,196,844.60$ & $196,155.50$ & $106,558,40$ & $6,462.40$ & $4,890,269.60$ \\
2003 & $413,877.70$ & $3,737,279.90$ & $196,156.90$ & $123,994.60$ & $7,020.20$ & $4,478,329.30$ \\
2002 & $375,700.10$ & $3,220,823.50$ & $182,964.50$ & $146,341.10$ & $7,055.60$ & $3,932,884.80$ \\
\hline
\end{tabular}

Source: Debt Management Office, Central Bank of Nigeria and Office of the Accountant General of the Federation.

Appendix B. Debt Service Payments and Debt Sustainability Indicators

\begin{tabular}{|c|c|c|c|c|c|c|c|c|c|c|c|}
\hline Indicators & $\begin{array}{c}\text { International } \\
\text { Threshold }\end{array}$ & 2011 & 2010 & 2009 & 2008 & 2007 & 2006 & 2005 & 2004 & 2003 & 2002 \\
\hline \multicolumn{12}{|l|}{ External Debt } \\
\hline $\begin{array}{l}\text { Service (Int. } \\
\text { Payments) }\end{array}$ & - & 18.4 & 15.3 & 17.4 & 9.0 & 117.2 & 831.04 & $1,130.13$ & NA & NA & NA \\
\hline $\begin{array}{l}\text { Amortization: } \\
\text { External Debt }\end{array}$ & Nil & 35.7 & 38 & 46.5 & 46.2 & 11.4 & 35.50 & 52.41 & 14 & NA & NA \\
\hline $\begin{array}{l}\text { Domestic Debt } \\
\text { Service(Int. } \\
\text { Payment) }\end{array}$ & Nil & 518.0 & 19.5 & 271.3 & 233.00 & 185.4 & 166.84 & 150.45 & NA & NA & NA \\
\hline & & 591.5 & 407.4 & 542.5 & 526.5 & 381.2 & $1,088.11$ & $1,331.99$ & - & - & - \\
\hline Total Debt/GDP & 30 & 18.4 & 17.8 & 15.1 & 11.5 & 12.5 & 11.8 & 28.7 & 53.6 & NA & NA \\
\hline $\begin{array}{l}\text { Total External } \\
\text { Debt/GDP }\end{array}$ & 30 & 2.5 & 2.3 & 2.3 & 2.1 & 2.1 & 2.4 & 18.3 & 41.9 & NA & NA \\
\hline $\begin{array}{l}\text { Total } \\
\text { Domestic/GDP }\end{array}$ & $40-60$ & 15.9 & 15.4 & 12.8 & 9.4 & 10.4 & 9.4 & 10.4 & 11.7 & & \\
\hline $\begin{array}{l}\text { Total External } \\
\text { Debt/Export (\%) }\end{array}$ & $100 \%$ & 5.8 & 6.3 & 7.0 & 4.3 & 5.3 & 6.3 & 37.2 & 106.2 & NA & NA \\
\hline $\begin{array}{l}\text { Total Debt } \\
\text { service/Revenue } \\
(\%)\end{array}$ & $20-25$ & 16.6 & 13.2 & 20.5 & 10.5 & 13.9 & 23.3 & 18.8 & 32.2 & NA & NA \\
\hline $\begin{array}{l}\text { Total Debt } \\
\text { /Revenue (\%) }\end{array}$ & 250 & 183.5 & 169.7 & 144.5 & 89.0 & 111.8 & 113.8 & 240.1 & 470.2 & NA & NA \\
\hline
\end{tabular}

Source: Debt Management Office, Central Bank of Nigeria and Office of the Accountant General of the Federation.

Appendix C. Nigeria: Selected Macroeconomic Indicators, 2002-2011 (in \%)

\begin{tabular}{lllllllllll}
\hline & $\mathbf{2 0 0 2}$ & $\mathbf{2 0 0 3}$ & $\mathbf{2 0 0 4}$ & $\mathbf{2 0 0 5}$ & $\mathbf{2 0 0 6}$ & $\mathbf{2 0 0 7}$ & $\mathbf{2 0 0 8}$ & $\mathbf{2 0 0 9}$ & $\mathbf{2 0 1 0}$ & $\mathbf{2 0 1 1}$ \\
\hline Growth of Net Credit (\%) & & & 12.0 & 14.5 & -69.1 & 276.4 & 84.3 & 59.2 & 10.0 & 42.4 \\
Real GDP(\%) & 21.35 & 10.23 & 10.48 & 6.5 & 6.03 & 6.5 & 6.41 & 6.53 & 7.87 & 7.56 \\
Goods Account/GDP(\%) & NA & NA & 22.5 & 25.7 & 24.0 & 22.7 & 22.1 & 15.0 & 13.4 & 12.7 \\
Rate of Inflation(\%) & NA & NA & 15.4 & 17.9 & 8.2 & 5.4 & 11.6 & 12.5 & 13.7 & 11.8 \\
Income Account Net/GDP & NA & NA & NA & -2.0 & -3.2 & -7.1 & -7.2 & -8.5 & -8.6 & -9.4 \\
\hline
\end{tabular}

Source: CBN Statistical Bulletin, Abuja.

\section{Copyrights}

Copyright for this article is retained by the author(s), with first publication rights granted to the journal.

This is an open-access article distributed under the terms and conditions of the Creative Commons Attribution license (http://creativecommons.org/licenses/by/3.0/). 